OPEN ACCESS

Edited by:

Howard A. Young,

National Cancer Institute at Frederick,

United States

Reviewed by:

Oleg A. Andreev,

University of Rhode Island,

United States

Blake Mertz,

West Virginia University, United States

${ }^{*}$ Correspondence:

Yi Wang

yk091023@163.com

Yanchun Shi

ycshi5388@163.com

Guojiang Chen

jyk62033@163.com

${ }^{\dagger}$ These authors have contributed

equally to this work

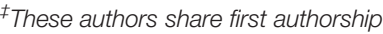

Specialty section:

This article was submitted to

Autoimmune and

Autoinflammatory Disorders,

a section of the journal

Frontiers in Immunology

Received: 13 October 2021 Accepted: 01 December 2021 Published: 23 December 2021

Citation:

Sun $Y, H u L$, Yang $P$,

Zhang $M$, Wang $X$, Xiao $H$,

Qiao C, Wang J, Luo L, Feng J,

Zheng $Y$, Wang $Y$, Shi $Y$ and Chen $G$ (2021) pH Low Insertion PeptideModified Programmed Cell DeathLigand 1 Potently Suppresses T-Cell Activation Under Acidic Condition.

Front. Immunol. 12:794226. doi: 10.3389/fimmu.2021.794226

\section{pH Low Insertion Peptide-Modified Programmed Cell Death-Ligand 1 Potently Suppresses T-Cell Activation Under Acidic Condition}

\author{
Ying Sun ${ }^{1,2 t \neq}$, Linhan $\mathrm{Hu}^{1,2 t \neq}$, Peng Yang ${ }^{1 \neq}$, Min Zhang ${ }^{2}$, Xinwei Wang ${ }^{1}, \mathrm{He} \mathrm{XiaO}^{2}$, \\ Chunxia Qiao ${ }^{2}$, Jing Wang ${ }^{2}$, Longlong Luo ${ }^{2}$, Jiannan Feng ${ }^{2}$, Yuanqiang Zheng ${ }^{1}$, \\ Yi Wang ${ }^{3 *}$, Yanchun Shi ${ }^{1 *}$ and Guojiang Chen ${ }^{2 *}$ \\ ${ }^{1}$ Inner Mongolia Key Lab of Molecular Biology, School of Basic Medical Sciences, Inner Mongolia Medical University, \\ Hohhot, China, ${ }^{2}$ State Key Laboratory of Toxicology and Medical Countermeasures, Institute of Pharmacology and \\ Toxicology, Beijing, China, ${ }^{3}$ Department of Hematology, The Fifth Medical Center, Chinese PLA General Hospital, \\ Beijing, China
}

Programmed cell death-ligand 1 (PD-L1)/PD-1 axis is critical for maintenance of immune homeostasis by limiting overactivation of effector $\mathrm{T}$-cell responses. The impairment of PDL1/PD-1 signals play an important role in the pathogenesis of inflammatory diseases, making this pathway an ideal target for novel therapeutics to induce immune tolerance. Given weakly acidic environment as a putative hallmark of inflammation, in this study we designed a new cargo by linking the ectodomain of murine PD-L1 to the $\mathrm{N}$ terminus of pHLIPs, a low pH-responding and membrane-insertion peptide, and demonstrated its potent immune-suppressive activity. Specifically, PD-L1-pHLIP spanned the cellular membrane and perfectly recognized its ligand PD-1 in acidic buffer. Immobile PD-L1pHLIP actively inhibited T-cell proliferation and IFN- $\gamma$ production. Importantly, soluble PDL1-pHLIP retained its function to dampen T-cell responses under acidic condition instead of neutral aqueous solution. Overall, these data suggest that PD-L1-pHLIP has potentials to be a novel therapeutic avenue for T-cell-mediated inflammatory diseases.

Keywords: PD-L1, pHLIP, inflammation, acidic, immunosuppression

\section{INTRODUCTION}

Programmed cell death-ligand 1 (PD-L1) is the ligand for the inhibitory PD-1 receptor, the latter expressed primarily on activated T cells (1). Crosslinking of PD-L1 and PD-1 inhibits T-cell proliferation and cytokine production, which is critical for the induction and maintenance of immune tolerance $(2,3)$. Genetic deletion of PD-1 leads to the development of various autoimmune diseases depending on the stains (4-6). Similarly, PD-L1 ${ }^{-1-}$ mice are more susceptible to experimental autoimmune encephalomyelitis, which is associated with the augmented responses of self-reactive $\mathrm{CD}^{+} \mathrm{T}$ cells in vivo (7). In nonobese diabetic (NOD) mice, PD-1 or PD-L1 deficiency accelerates the onset of type 1 diabetes $(3,8)$. Of note, transgenic expression of PD-L1 in pancreatic $\beta$ cells in NOD mice significantly decreases the severity of insulitis and delays disease 
onset as well as reduces the incidence of diabetes $(9,10)$, indicating that increased expression of PD-L1 in the lesions represents a potentially therapeutic strategy for autoimmune diseases.

Chronic inflammation is the hallmark of autoimmune diseases, characterized by massive infiltration and activation of immune cells $(11,12)$. Notably, enhanced glycolysis inherently occurs in lipopolysaccharide (LPS)-activated macrophages and dendritic cells $(13,14)$, in activated effector T cells, as well as other lymphocytes (15-17), which enables the immune cell to generate sufficient ATP and biosynthetic intermediates to carry out its particular effector functions $(18,19)$. Consequently, lactate, the well-known byproducts of glycolysis, accumulates in extracellular space, leading to acidosis (conventionally less than 7.0 of pH) at the site of inflammation (20-22). pHLIPs are a family of soluble $\sim 36$ amino acid peptides with $\mathrm{pH}$-dependent transmembrane activity (23). When the environment is acidic, a pHLIP folds and inserts across the membrane to form a stable transmembrane helix, thus preferentially locating itself in acidic tissues (24). The low-pH targeting behavior of pHLIPs leads to applications as carriers for diagnostic and surgical imaging agents or delivery of cell-impermeable cargos into the cytosol of targeted cells $(25,26)$. In addition, a variety of other cargos, such as small molecule antigen (e.g. 2,4-dinitrophenyl (DNP)), can be associated with $\mathrm{N}$ terminus of pHLIPs and specifically targeted to the surfaces of cancer cells to induce biological responses, since tumors are putatively acidic (27). In this study, we engage the extracellular region of murine PD-L1 with the $\mathrm{N}$ terminus of pHLIPs and evaluate the function of this fusion protein (PD-L1-pHLIP) to suppress lymphocyte expansion and cytokine production in acidic buffer, providing a potentially innovative avenue to treat inflammatory autoimmune diseases.

\section{MATERIALS AND METHODS}

\section{Expression and Purification of Recombinant Proteins}

The amino acid sequences of recombinant proteins used in this study were indicated as below. All constructs carried a Cterminal histidine tag or IgG1 Fc fragment for purification and were cloned into pMT-puro vectors for expression in HEK293 cells. Stably transfected cells were selected with $6 \mu \mathrm{g} / \mathrm{ml}$ puromycin. The resulting proteins were purified using $\mathrm{Ni}$ affinity or protein A agarose affinity chromatography column (Cytiva, Amersham Place, UK) followed by further purification by SEC using a Superdex 200 (S200) column with $10 \mathrm{mM}$ Tris and $150 \mathrm{mM} \mathrm{NaCl}, \mathrm{pH} 7.5$ (1× TBS). The purity of recombinant proteins was determined by SDS-PAGE (GenScript, Nanjing, China).

Protein sequences used in this study:

Murine PD-L1-WT pHLIP (wild-type pHLIP was used here, denoted to PD-L1-pHLIP):

MDAMKRGLCCVLLLCGAVFVSNSHHHHHHHHFTITA PKDLYVVEYGSNVTMECRFPVERELDLLALVVYWEKEDE Q V I Q F V A G
EEDLKPQHSNFRGRASLPKDQLLKGNAALQITDVKLQ DAGVYCCIISYGGADYKRITLKVNAPYRKINQRISVD P A T S E H E L I C Q AEGYPEAEVIWTNSDHQPVSGKRSVTTSRTEGMLek? $>$ L N V T S S L R V

NATANDVFYCTFWRSQPGQNHTAELIIPELPATH PPQNRTGGGGSGGGGSGGGGSAEQNPIYWARYAD WLFTTPLLLLDLALLVDADEGT

Murine PD-L1-mFc (denoted to PD-L1-Fc):

M D A M K R G L C C V L L L C G A V F V S N S F T I T A PKDLYVVEYGSNVTMECRFPVERELDLLALVVYWEKE DEQVIQFVAGEEDLKPQHSNFRGRASLPKDQLLKGNAA LQITDVKLQDAGVYCCIISYGGADYKRITLKVNAPYRKINQ RISVDPATSEHELICQAEGYPEAEVIWTNSDHQPVSGKRS V T T S R T E G M L L N V T S L R V N A T A

N D V F Y C T F W R Q P G Q N H T

A E L I P E L P A T H P P Q N T D D D D K A V P R D G C K P C I C T V P E V S S V F I F P P K P K D V L T I T L T P K V T C V V V D I K D D P E V Q F W F V D D V E V H T A Q T Q P R E E F N S T F S V S E L P I M H Q D W LNGKEFKCRVNSAAFPAPIEKTISKTKGRPKAPQVYT I P P P K E Q M A K D K V S L T

C M I T D F F P D I T V E W Q W N G Q P A E N Y K T Q P I M D T D G S Y F V Y S

KLNVQKSNWEAGNTFTCSVLHEGLHNHHTEKSLSHSPGK

Murine PD-L1-mutated WT pHLIP (denoted to PD-L1$\mathrm{pHLIP}(\mathrm{m}))$ :

MDAMKRGLCCVLLLCGAVFVSNSHНHНHНHНF TITAPKDLYVVEYGSNVTMECRFPVERELDLLALVVYW E K E D E Q V I Q F V A G E E D L K P Q H SNFRGRASLPKDQLLKGNAALQITDVKLQDAGVYCCIISY GGA D Y KRITLKVNA PYRKINQRIS V D P A T S HE LICQAEGYPEAEVIWTNSDHQPVSGKRSVTTSRT E G M L 1 L N V T S L R V N A T A N D F Y CT F W R Q P G Q N H T A E LIIPELPA T H P P Q R T G G G G S G G G G S G G G G S A C E Q N P IYWARYAKWLFTTPLLLLKLALLVDADEGT

EBOV-secreted glycoprotein (sGP)-WT pHLIP (denoted to control protein):

M D A M K R G L C C V L L L C G A V F V S N S

H H H H H H I P L G V I H N S T Q V S D V D K L V C R D K L S S T N Q L S V G L N L E G N G V A T D V PSATKRWGFRSGVPPKVVNYEAGEWAENCYNLEIKK PDGSECLPAAPDGIRGFPRCRYVHKVSGTGPCAGDF A F H K E G A F F L Y D R L A S T V I Y R G T T F A E G V V A F L I L Q A K K D F F S H P L R E P V N A T E D P S G Y Y S T T I R Q A T G F G T N E T E Y L F E V D N L T Y V Q L E S R F T P Q FLLQLNETIYASGKRSNTTGKLIWKVNPEIDTTIGEWAFWE T K G G G G S G G G G S G G G G S A C E Q N PIYWARYADWLFTTPLLLLDLALLVDADEGT

\section{ELISA}

A total of 96-well plated were coated overnight with the indicated antigens at 2 or $5 \mu \mathrm{g} / \mathrm{ml}$, washed three times with PBS-T, and blocked with $4 \%$ nonfat dried milk in PBS for $1 \mathrm{~h}$ at room temperature. Twofold serial dilution of biotin-labeled anti-mPD- 
L1 antibody (BioLegend, San Diego, CA, USA) from $6 \mu \mathrm{g} / \mathrm{ml}$ was measured. For mPD-1, which was biotinylated according to manufacturer's instructions (Genemore, Shanghai, China), it was added at 25,50, and $100 \mu \mathrm{g} / \mathrm{ml}$ and incubated for $1 \mathrm{~h}$ at room temperature. The wells were washed and avidinconjugated HRP $(1: 4,000)$ in $0.5 \%$ BSA was added and incubated for $1 \mathrm{~h}$ at room temperature. A TMB substrate kit (Invitrogen, Waltham, MA, USA) was used for detection at 450 $\mathrm{nm}$. IFN- $\gamma$ levels in the supernatants were determined by sandwich ELSA assays (BioLegend, CA, USA).

\section{Cell Culture and Transient Transfection}

Cell lines (THP-1, Raji, Jurkat, and HEK293T) were purchased from ATCC and cultured in Dulbecco's modified Eagle's medium (DMEM) or RPMI 1640 medium (Gibco, Waltham, MA, USA) supplemented with $10 \%$ fetal bovine serum and penicillin/streptomycin in a humidified atmosphere of $5 \% \mathrm{CO}_{2}$ at $37^{\circ} \mathrm{C}$. HEK293T cells were transiently transfected with mPD-1 and $\mathrm{mPD}-\mathrm{L} 1$ expression plasmids using a PEI transfection protocol (Promega, Madison, WI, USA), respectively. $48 \mathrm{~h}$ later, the expression of PD-L1 and PD-1 on the surface of cells was detected by flow cytometry.

\section{Fluorescence Labeling of Proteins and Confocal Microscopic Imaging}

Recombinant proteins were labeled by fluorescence dye (PE or AlexaFlour488) with Conjugation Kit, according to manufacturer's protocol (Abcam, Cambridge, UK). The HEK293T or HCT116 cell lines were placed in a laser confocal dish (NEST, Wuxi, China) and cultured overnight. AlexaFlour488-conjugated protein was added at $10 \mu \mathrm{g} / \mathrm{ml}$ and cultured at $37^{\circ} \mathrm{C}$ for $1 \mathrm{~h}$. Cells were washed twice with PBS with corresponding $\mathrm{pH}$, and then the fluorescence on the surface of cell membrane was observed under confocal laser scanning microscope (Zeiss LSM880, Jena, Germany).

\section{Lymphocyte Isolation and BrdU Cell Proliferation Assays}

The splenocytes of BALB/c mice (purchased from Charles River, Beijing, China) were isolated by gradient centrifugation. Human PBMC were isolated from whole blood of healthy donors with signed written informed consents. The indicated proteins at titrated concentrations were coated in 96-well plates (Corning, Christiansburg, VA, USA) at $4^{\circ} \mathrm{C}$ overnight. Lymphocytes were added $\left(5 \times 10^{5}\right.$ cells/well) with stimulation of anti-CD3 and CD28 antibody cocktail (10 and $5 \mu \mathrm{g} / \mathrm{ml}$, respectively) for $72 \mathrm{~h}$. BrdU cell proliferation assays were performed according to the manufacturer's protocol (Cell Signaling, Danvers, MA, USA). In addition, lymphocytes were treated as described above with soluble proteins indicated in PBS with corresponding $\mathrm{pH}$ or containing lactic acid (10 or $20 \mathrm{mM}$ ). In some settings, neutralizing mAbs to murine PD-1 or PD-L1 (10 $\mu \mathrm{g} / \mathrm{ml}$, BioLegend, CA, USA) were added.

\section{Flow Cytometry}

The cells were incubated with PE-labeled proteins as indicated at $0.001-10 \mu \mathrm{g} / \mathrm{ml}$ for $0.5-4 \mathrm{~h}$ in PBS with corresponding $\mathrm{pH}$ or containing lactic acid (10 or $20 \mathrm{mM})$. In some settings, cells were incubated with the indicated proteins at $10 \mu \mathrm{g} / \mathrm{ml}$ for $1 \mathrm{~h}$ in PBS ( $\mathrm{pH} 7.4$ and 6.3). PE-labeled mPD-1 was added and incubated for another $30 \mathrm{~min}$. Cells were washed twice with PBS with corresponding $\mathrm{pH}$, and then detected by flow cytometry.

For BrdU incorporation, mouse spleen lymphocytes were treated as described above. Six hours before the end of stimulation, BrdU solution (Sigma, Darmstadt, Germany) with the final concentration of $10 \mu \mathrm{M}$ was added. Cells were washed and incubated with APC-antimouse CD4/CD 8 antibody (BioLegend, CA, USA) at $4^{\circ} \mathrm{C}$ for $30 \mathrm{~min}$. After washing, fixing, and permeabilizing (Invitrogen, MA, USA), cells were incubated with PE-antimouse BrdU antibody (BioLegend, CA, USA) in the dark at $4^{\circ} \mathrm{C}$ for another $30 \mathrm{~min}$. The fluorescence intensity was measured by FACS Calibur II (BD Biosciences, CA, USA).

\section{Quantitative RT-PCR}

Extracted total mRNA with TRIzol reagent, Single-strand cDNA was made from $1 \mu \mathrm{g}$ total RNA by reverse transcription (RT) using a TransScript II First-Strand cDNA Synthesis SuperMix (TransGen Biotech, Beijing, China). qPCR was conducted using SYBR Green qPCR mixture (GenStar, Beijing, China) through 50 cycles in a IQ5 Real-Time PCR Detection Systems (Bio-Rad, Hercules, CA, USA). The sequences of the primers used for qPCR were as follows: the forward primer of mouse IFN- $\gamma$ is $5^{\prime}$ ACAGCAAGGCGAAAAAGGATG-3' and the reverse primer is 5'-TGGTGGACCACTCGGATGA-3'. The forward primer of mouse GAPDH is 5'-CATCAAGAAGGTGGTGAAGC-3' and the reverse primer is 5'-CCTGTTGCTGTAGCCGTATT-3'. Data were analyzed using the delta-delta $\mathrm{Ct}$ method.

\section{Statistical Analysis}

Data are expressed as the means \pm SD according to at least 3 independent experiments. Two-tailed Student's $t$-tests were used to compare experimental and control groups. Statistical significance is defined as $p<0.05$.

\section{RESULTS}

\section{Recombinant Murine PD-L1-pHLIP Perfectly Binds to Its Ligand PD-1}

Firstly, the extracellular region of mouse PD-L1 was conjugated to the $\mathrm{N}$ terminus of wild-type pHLIPs using $(\mathrm{G} 4 \mathrm{~S})_{3}$ as a coupling linker and the fusion protein generated in the eukaryotic expression system. As well, PD-L1 (having His tags) and PD-L1-Fc protein were also expressed using the same methods. The identities of these proteins were validated by SDS-PAGE (Figure 1A). Secondly, to determine whether pHLIP attachment affected native conformation of PD-L1, three experiments were performed as following: (1) The recognition of an antimurine $\mathrm{PD}-\mathrm{L} 1$ antibody to these proteins was examined. The $\mathrm{EC}_{50}$ of PD-L1, PD-L1-pHLIP, and PD-L1FC was $0.017,0.024$, and $0.016 \mu \mathrm{g} / \mathrm{ml}$, respectively (Figure 1B). This result indicated that these fusion proteins retained primary 


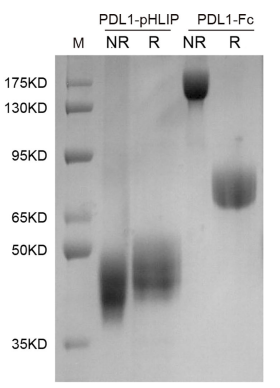

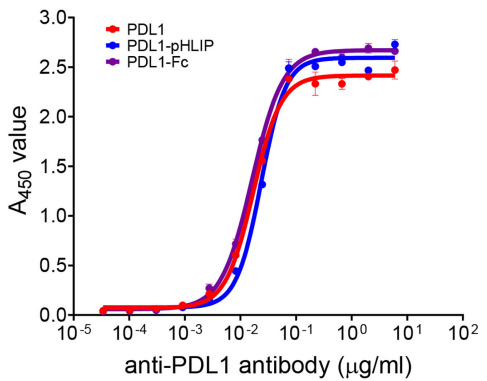

C

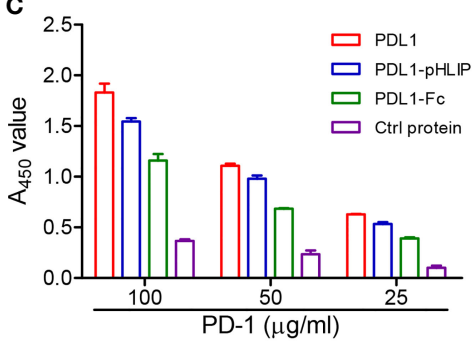

D
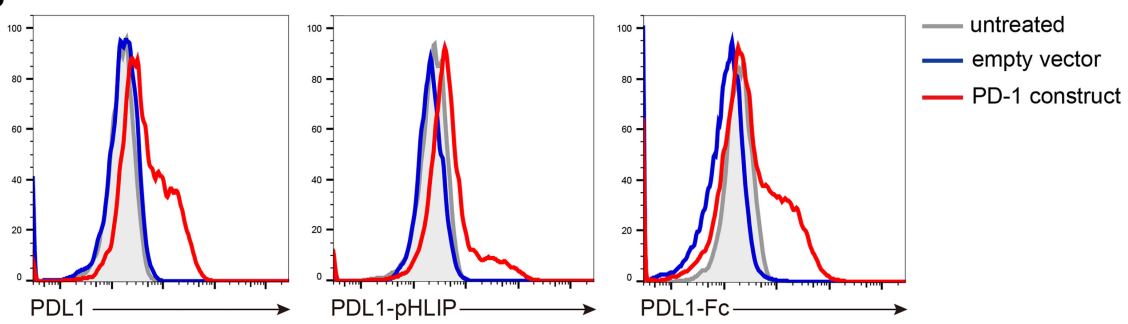

FIGURE 1 | Validation of recombinant mouse PD-L1-pHLIP protein binding its ligand PD-1. (A) Recombinant PD-L1-pHLIP and PD-L1-Fc proteins were examined by SDS-PAGE. R, reducing; NR, nonreducing. (B) The binding capacity of PD-L1/PD-L1-pHLIP/PD-L1-FC to an anti-PDL1 monoclonal antibody was determined by ELISA. (C) The ability of PD-L1/PD-L1-pHLIP/PD-L1-FC to bind recombinant PD-1 protein was determined by ELISA. (D) Murine PD-1 construct was transiently introduced into HEK293T cell lines. The engagement of PE-conjugated PD-L1/PD-L1-pHLIP/PD-L1-Fc with membrane-bound PD-1 on the surface of HEK293T cells was examined by flow cytometry. Representative plots from three independent experiments were shown. The data were pooled from three experiments with similar results.

antigenic epitopes recognized by specific antibodies. (2) The binding capacity of these proteins to PD-1 was detected. Recombinant PD-1 protein (extracellular region) was expressed eukaryotically as described above (Figure S1A). To determine the binding ability of $\mathrm{PD}-1$ protein to $\mathrm{PD}-\mathrm{L} 1$, murine $\mathrm{PD}-\mathrm{L} 1$ constructs were introduced into HEK293T cell line and its expression was confirmed by flow cytometry (Figure S2A). Importantly, fluorescence-labeled PD-1 protein was shown to recognize PD-L1-overexpressing HEK293T cells rather than empty vector-introduced controls (Figure S1B). Thereafter, the binding ability of these proteins to PD-1 was examined by ELISA. As shown in Figure 1C, the similar PD-1-bound capacity of PD-L1, PD-L1-pHLIP, and PD-L1-Fc was observed, suggesting that pHLIP conjugation did not influence the interaction between PD-L1 and PD-1. (3) The engagement of these proteins to membrane-bound PD-1 was determined. Murine PD-1 constructs were introduced into HEK293T cells, and its expression was validated (Figure S2B). The results showed that fluorescence-conjugated PD-L1, PD-L1-pHLIP, and $\mathrm{PD}-\mathrm{L} 1-\mathrm{Fc}$ could recognize $\mathrm{PD}-1-\mathrm{knockin}$ cells rather than empty vector-knockin controls (Figure 1D). Overall, these data indicate that pHLIP attachment has no significant effects on the engagement of PD-L1 fragment to PD-1.

\section{PD-L1-pHLIP Has Excellent Low pH- Responding Potentials to Insert the Membrane in Acidic Buffer}

Whether PD-L1-pHLIP retains membrane-inserting capacity is an important issue for the implementation of its immunesuppressive function under acidic condition. To address this, several cell lines (HEK293T, THP-1, Raji, Jurkat) were incubated with fluorescence-labeled PD-L1-pHLIP for $1 \mathrm{~h}$ in $\mathrm{pH} 7.4$ or 6.3 solutions and then detected by flow cytometry. No fluorescence was found in neutral aqueous solutions. In contrast, high magnitudes of fluorescence were visible in $\mathrm{pH} 6.3$ buffer (Figure 2A), indicating that under acidic condition, PD-L1- 
pHLIP undergo conformational changes from random coil to $\alpha$ helix and spans the cellular membrane. Moreover, fluorescent imaging also identified the exhibition of fluorescence-conjugated PD-L1-pHLIP on the cell surface in pH6.3 buffer instead of pH7.4 solutions (Figure 2B). Furthermore, we examined its membrane-inserting capacity in primary lymphocytes. As expected, PD-L1-pHLIP could potently spanned and displayed on the surface of mouse and human lymphocytes in pH6.3 buffer (Figure 3A). To accurately mimic acidic microenvironment in vivo, $\mathrm{pH}$ was titrated by lactic acid (10 or $20 \mathrm{mM})$. Similar effects were observed (Figure 3B), which had important implications for the administration of PD-L1-pHLIP in vivo.

Thereafter, we determined the membrane-spanning ability of PD-L1-pHLIP in the intervals of 0-4 hours under neutral or acidic conditions. PD-L1-pHLIP did not display membraneinserting potentials in pH7.4 buffer, even for longer incubation time (Figure S3). Conversely, in acidic buffer, fluorescence intensity reach the peak at 1 hour after incubation, and then decreased over time. At 4-hour timepoint, the intensity remained relatively high (Figure 4A). Furthermore, we determined whether PD-L1-pHLIP insertion was dose and $\mathrm{pH}$ dependent. Indeed, fluorescence intensity of PD-L1-pHLIP elevated dramatically with the increase of concentration (Figure 4B). In a range of $\mathrm{pH}$ 6.0-7.4, the fluorescence intensity increased when $\mathrm{pH}$ of the solution was titrated (Figure 4C). Notably, significant elevation of the intensity was seen when $\mathrm{pH}$ value jumped down from 6.5 to 6.3 (Figure 4C), which might be associated with conformational transformation of PD-L1-pHLIP from the mixture of membrane-absorbed and membrane-inserted states to fully membrane-inserted states (28).

Next, we asked whether PD-L1-pHLIP displayed on the surface of cells could recognize PD-1 smoothly. PD-1 protein was labeled with fluorescent dye and added to THP-1 cell lines, which were preincubated with PD-L1-pHLIP in $\mathrm{pH} 7.4$ or 6.3 buffer. No significant fluorescence was seen in neutral solution. In contrast, fluorescence was obvious in $\mathrm{pH} 6.3$ buffer (Figure S4A). We also examined the engagement of fluorescence-conjugated PD-1 to other proteins (PD-L1, PD-L1-Fc, mutated PD-L1-pHLIP [named PD-L1-pHLIP(m)], control protein (EBOV sGP-pHLIP) under the same condition. No fluorescence was found (Figure S4B). Taken together, these data clearly indicate that PD-L1 attachment does not impair the acid-responding and membrane-spanning ability of pHLIPs and that its conformational changes have no or minimal effects on the interaction between PD-L1 and PD-1.

\section{Immobile PD-L1-pHLIP Potently Inhibits Lymphocyte Expansion and IFN- $\gamma$ Secretion}

We next determine the immune-suppressive activity of platecoated PD-L1-pHLIP. As well known, PD-L1 delivers signals to T cells via binding to its ligands PD-1 or CD80 (29). PD-L1/PD-1 interaction is responsible for executing the immune-suppressive function of PD-L1. The expression levels of PD-1 in CD4 ${ }^{+}$and $\mathrm{CD}^{+} \mathrm{T}$ cells at different timepoints following TCR stimulation

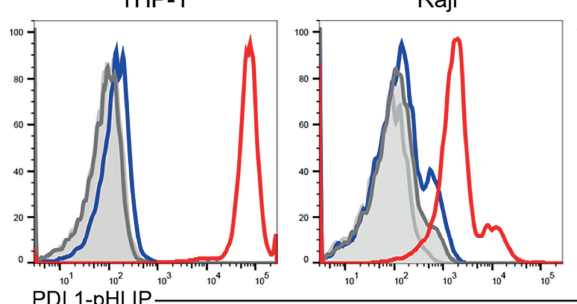

PDL1-pH $0^{10^{2}}$
Jurkat

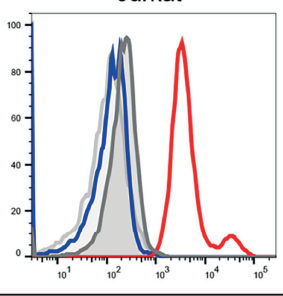

HEK293T

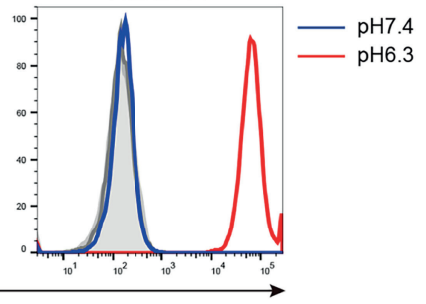

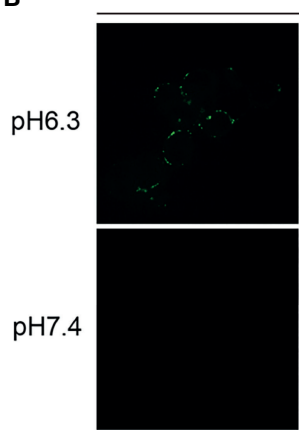

HEK293T

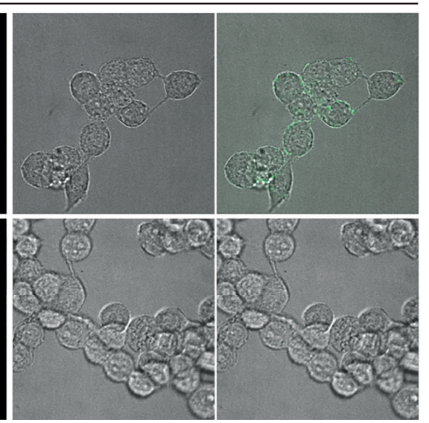

HCT116

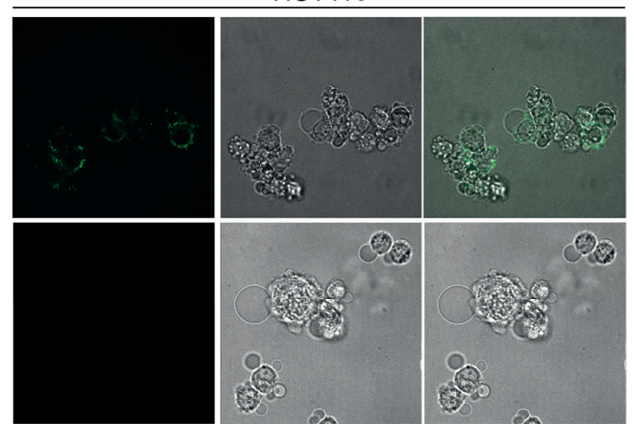

FIGURE 2 | The low pH-responding ability of PD-L1-pHLIP to insert into cell membrane. (A) PE-conjugated PD-L1-pHLIP (10 $\mu$ g/ml) was incubated with different cell lines indicated in $\mathrm{pH} 7.4$ or 6.3 buffer for $1 \mathrm{~h}$, respectively. The insertion ability was examined by flow cytometry. (B) AF488-conjugated PD-L1-pHLIP (10 $\mu$ g/ml) was incubated with HEK293T or HCT116 cell lines in $\mathrm{pH} 7.4$ or 6.3 buffer for $1 \mathrm{~h}$, respectively. The insertion ability was examined by microscopic imaging.

Representative images from three independent experiments were shown. 

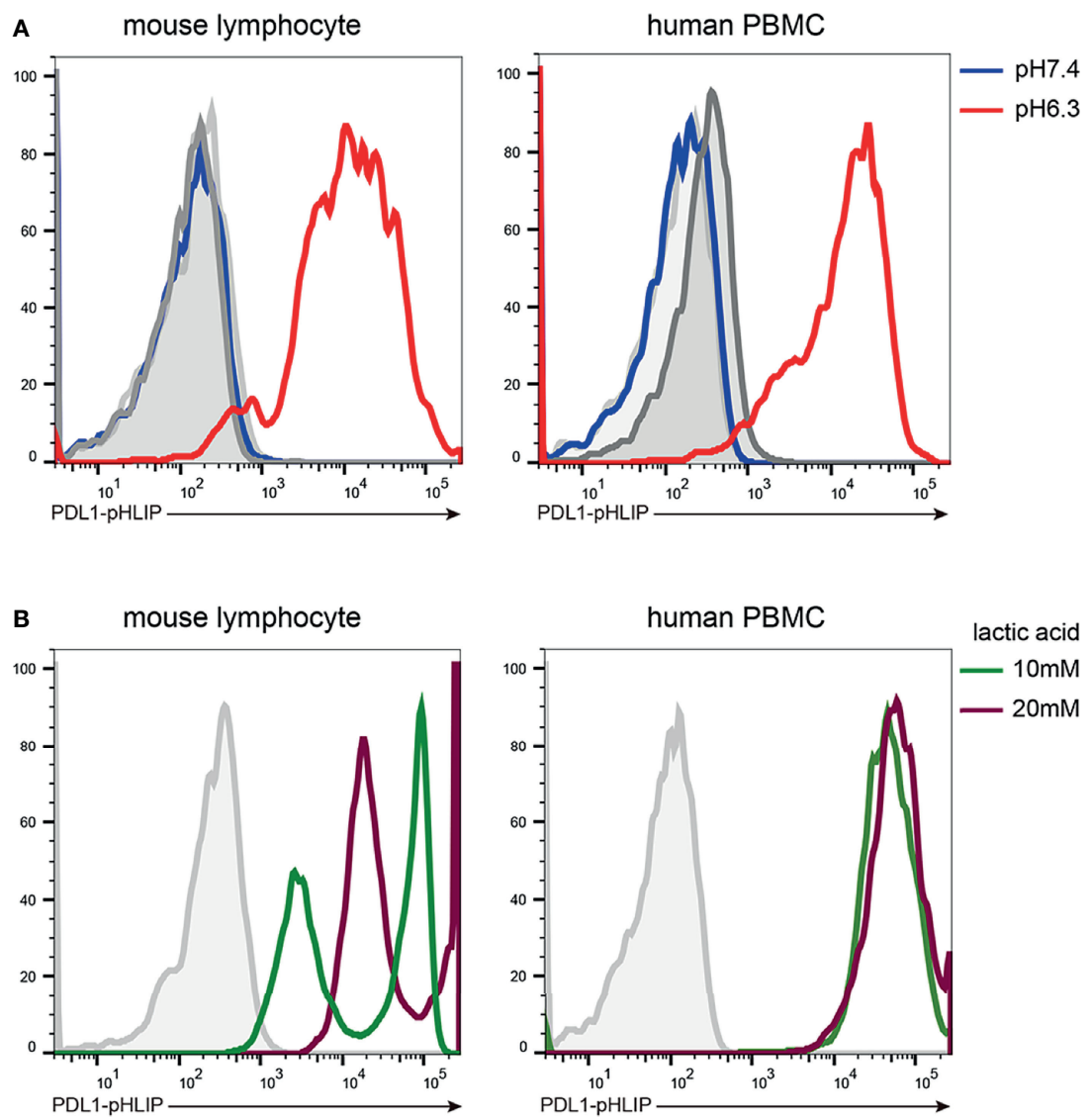

FIGURE 3 | The low pH-responding ability of PD-L1-pHLIP to insert into primary murine and human lymphocytes. Mouse lymphocytes and human PBMC were isolated from the spleen of Balb/c strain and heathy volunteers, respectively. PE-conjugated PD-L1-pHLIP (10 $\mu \mathrm{g} / \mathrm{ml})$ were incubated with these cell populations for 1 h in $\mathrm{pH} 7.4$ or 6.3 buffer (A) or buffer containing 10 or $20 \mathrm{mM}$ lactic acid (B). The fluorescence was examined by flow cytometry. Representative plots from three independent experiments were shown.

were detected respectively. In terms of $\mathrm{CD} 4^{+} \mathrm{T}$ cells, PD-1 levels were significantly elevated at $24 \mathrm{~h}$ post-treatment with the cocktail of anti-CD3/CD28 mAbs. Its expression was further augmented at 48 and $72 \mathrm{~h}$ (Figure S5). The distinct expression patterns of $\mathrm{PD}-1$ were observed in $\mathrm{CD}^{+} \mathrm{T}$ cells. $\mathrm{PD}-1$ levels in $\mathrm{CD}^{+} \mathrm{T}$ cells at $24 \mathrm{~h}$ were comparable with the resting cells. Its expression, however, increased drastically at 48 and $72 \mathrm{~h}$ following TCR stimulation (Figure S5).

Thereafter, we evaluated the function of plated-bound proteins (PD-L1-pHLIP, PD-L1, PD-L1-Fc, control protein) to inhibit proliferation of lymphocytes at the intervals of 24-72 h following treatment with anti-CD3/CD28 mAbs. At $24 \mathrm{~h}$ poststimulation, none of them (i.e., PD-L1-pHLIP, PD-L1, PD$\mathrm{L} 1-\mathrm{Fc}$ ) displayed inhibitory function. All of them, however, actively suppressed lymphocyte expansion at 48 and $72 \mathrm{~h}$ following TCR stimulation, with over $90 \%$ of inhibition rates (Figure 5A). Notably, control protein-conjugated pHLIPs did not exhibit proliferation-inhibitory capacity (Figure 5A). We further determine the dose-dependent effects of these proteins in a range of $0.01-1 \mu \mathrm{g} / \mathrm{ml}$. The result showed that immobile proteins (PD-L1-pHLIP, PD-L1, PD-L1-Fc) still retained the strong potency of inhibition of lymphocyte proliferation at low concentration $(0.01 \mu \mathrm{g} / \mathrm{ml})$ (Figure 5B). To clarify the effects of these proteins on $\mathrm{T}$-cell subsets, BrdU was incorporated into lymphocytes, followed by the detection of the frequencies of $\mathrm{BrdU}^{+}$cells in $\mathrm{CD}^{+}$and $\mathrm{CD}^{+}{ }^{\mathrm{T}}$-cell populations, respectively. These proteins (PD-L1-pHLIP, PD-L1-Fc), indeed, potently inhibited the expansion of $\mathrm{CD}^{+}$and $\mathrm{CD}^{+} \mathrm{T}$ cells simultaneously (Figure 5C). As well, immobile proteins were able to repress IFN- $\gamma$ production by activated lymphocytes at the protein and mRNA levels (Figures 5D, E). To determine whether PD-L1/PD-1 ligation was responsible for the inhibitory function of PD-L1-pHLIP, neutralizing antibodies to PD-L1 and PD-1 were added. Blocking PD-L1/PD-1 interaction using anti-PD-L1 or PD-1 antibody almost entirely abrogated the inhibitory ability of PD-L1-pHLIP, including suppressing lymphocyte proliferation and IFN- $\gamma$ secretion (Figures 5F, G). Overall, these results indicate that plate-bound PD-L1-pHLIP actively inhibits $\mathrm{T}$ lymphocyte expansion and cytokine production via binding to $\mathrm{PD}-1$ receptor on the surface of $\mathrm{T}$ cells. 

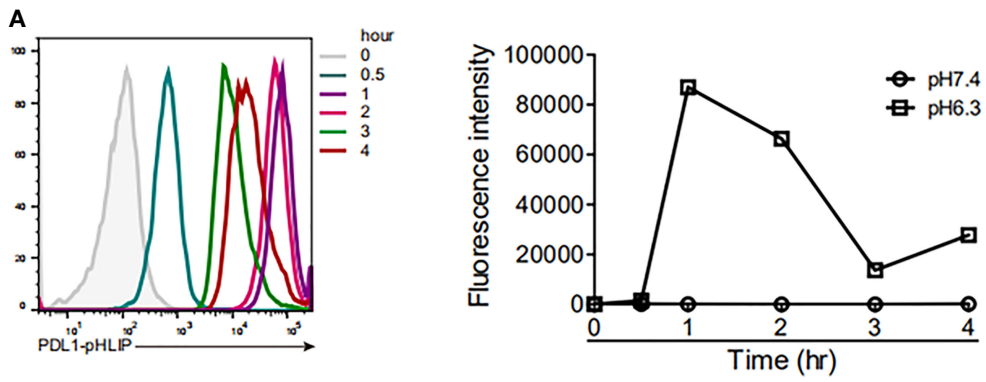

B
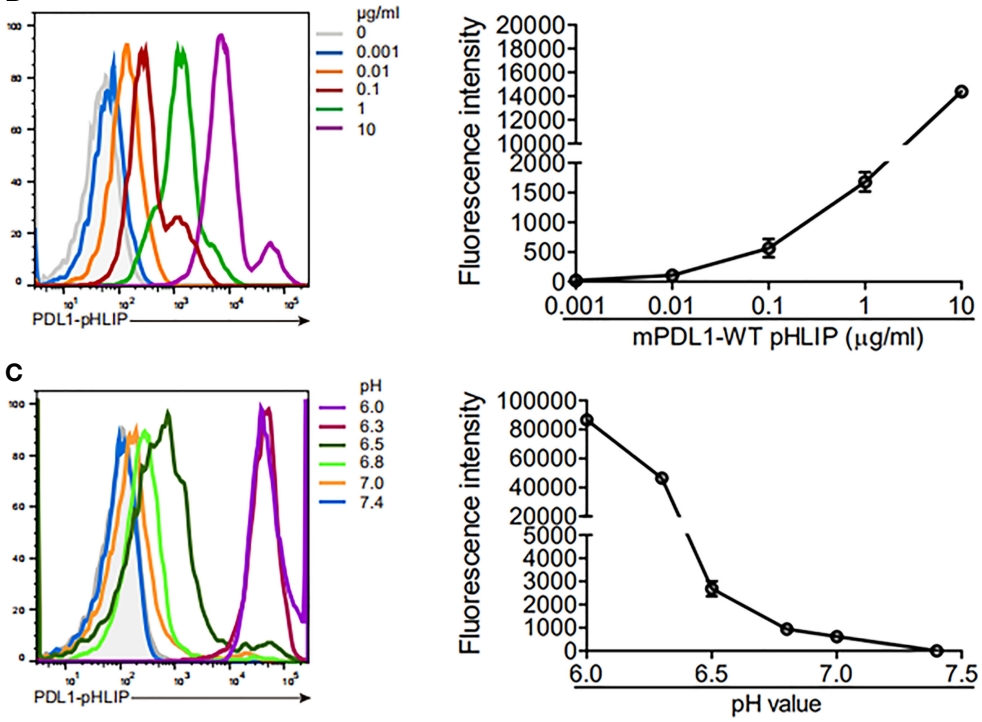

FIGURE 4 | The ability of PD-L1-pHLIP to span across cell membrane under titrated conditions. (A) THP-1 cell lines were incubated with PE-conjugated PD-L1$\mathrm{pHLIP}(10 \mu \mathrm{g} / \mathrm{ml})$ for $0-4 \mathrm{~h}$ in $\mathrm{pH} 6.3$ buffer and then examined by flow cytometry. (B) PE-conjugated PDL1-pHLIP (0-10 $\mu \mathrm{g} / \mathrm{ml})$ were incubated with THP-1 cell line for $1 \mathrm{~h}$ in $\mathrm{pH} 6.3$ buffer and then examined by flow cytometry. (C) THP-1 cell lines were incubated with PE-conjugated PD-L1-pHLIP (10 $\mu$ g/ml) for $1 \mathrm{~h}$ in pH 6.0-7.4 buffer and then examined by flow cytometry. Left, representative plots from three independent experiments. Right, the data of fluorescence intensity pooled.

\section{PD-L1-pHLIP Exhibits Inhibitory Effects on Lymphocyte Proliferation and IFN- $\gamma$ Production in Acidic Buffer}

To test our hypothesis that under acidic conditions, PD-L1pHLIP inserts and spans cellular membrane through conformational changes from unstructured coil to $\alpha$ helix, thereby playing an immune-suppressive role in T-cell activation via the interaction between $\mathrm{PD}-\mathrm{L} 1$ and $\mathrm{PD}-1$, we determined the inhibitory function of these proteins (PD-L1-pHLIP, PD-L1, PD$\mathrm{L} 1-\mathrm{Fc}$ ) at the soluble state in $\mathrm{pH} 6.3$ or 7.4 buffer respectively. As expected, these proteins at the soluble state did not suppress lymphocyte proliferation and IFN- $\gamma$ secretion in neutral aqueous solution (Figures S6A, B). Of importance, in acidic buffer, soluble PD-L1-pHLIP robustly repressed lymphocyte expansion and IFN- $\gamma$ production (Figures 6A, B). In contrast, PD-L1 and PDL1-Fc had no inhibitory effects on lymphocyte activation under the same condition (Figures 6A, B). We further evaluated the function of these proteins in the solution containing $10 \mathrm{mM}$ lactic acid. Similarly, PD-L1-pHLIP displayed significantly inhibitory function on lymphocyte proliferation and IFN- $\gamma$ production, instead of PD-L1 and PD-L1-Fc (Figures 6C, D). Taken together, these data suggest that PD-L1-pHLIP actively suppresses $\mathrm{T}$-cell activation under acidic condition.

\section{DISCUSSION}

The therapy for autoimmune diseases currently focus on the development of antagonists to block effector functions of one cytokine (e.g., IL-6, TNF- $\alpha$, IL-17A, etc.) (30, 31). However, the onset of autoimmune diseases is well-known to result from the orchestrated effects of a variety of cytokines (32). In this study, we provide the proof of concept that PD-L1-pHLIP is designed to down-regulate the effector function of autoreactive $\mathrm{T}$ cells in the sites of inflammation, which is considered acidic. Given whole suppression of effector T-cell response instead of targeting one inflammatory mediators, PD-L1-pHLIP theoretically might be more effective to treat autoimmune diseases than targeting one cytokine, which need validation in vivo in the future. The reasons for choosing PD-L1 as a cargo are following: (a) PD-L1/PD-1 interaction is definitely critical to maintain T-cell tolerance and immune homeostasis. Long-term administration of PD-1 

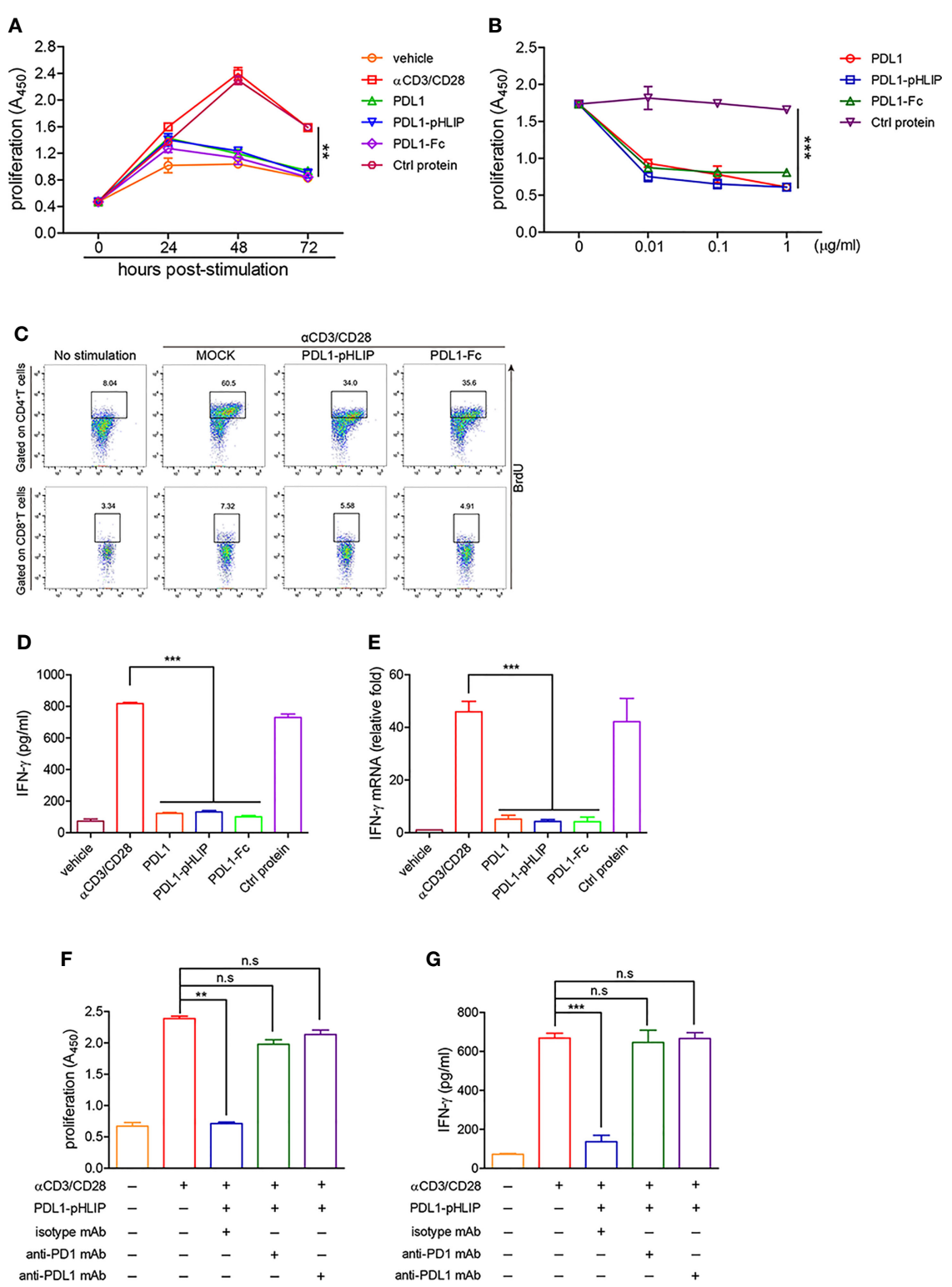

FIGURE 5 | The capacity of immobile PD-L1-pHLIP to inhibit lymphocyte proliferation and IFN- $\gamma$ production. (A) PD-L1/PD-L1-pHLIP/PD-L1-FC or control protein $(0.1 \mu \mathrm{g} / \mathrm{ml})$ were coated in culture plates overnight. Mouse lymphocytes were isolated and stimulated with $\alpha \mathrm{CD} 3 / \mathrm{CD} 28$ antibodies for $0-72 \mathrm{~h}$. The proliferation was determined by BrdU cell proliferation assays. (B) Mouse lymphocytes were stimulated with $\alpha C D 3 / C D 28$ antibodies in the absence or presence of immobile PD-L1/ PD-L1-pHLIP/PD-L1-Fc (0-1 $\mu \mathrm{g} / \mathrm{ml})$ for $72 \mathrm{~h}$. The proliferation was determined by BrdU cell proliferation assays. (C) Mouse lymphocytes were stimulated with $\alpha \mathrm{CD} 3 /$ CD28 antibodies in the presence of immobile PD-L1/PD-L1-pHLIP/PD-L1-FC $(0.1 \mu \mathrm{g} / \mathrm{ml})$ for $72 \mathrm{~h}$. BrdU $(10 \mu \mathrm{M})$ was incorporated at last $6 \mathrm{~h}$. The proliferation of $\mathrm{CD}^{+}$or $\mathrm{CD} 8^{+} T$ lymphocytes was determined by flow cytometry. (D, E) Mouse lymphocytes were stimulated with $\alpha \mathrm{CD} 3 / \mathrm{CD} 28$ antibodies in the presence of immobile PD-L1/PD-L1-pHLIP/PD-L1-FC $(0.1 \mu \mathrm{g} / \mathrm{ml})$ for $72 \mathrm{~h}$. IFN- $\gamma$ expression was examined by ELISA (D) and quantitative RT-PCR (E), respectively. (F, G) Mouse lymphocytes were stimulated with $\alpha \mathrm{CD} 3 / \mathrm{CD} 28$ antibodies in the presence of immobile PD-L1/PD-L1-pHLIP/PD-L1-Fc $(0.1 \mu \mathrm{g} / \mathrm{ml})$ for $72 \mathrm{~h}$. Monoclonal antibodies to PD-1 or PD-L1 or isotypes $(10 \mu \mathrm{g} / \mathrm{ml})$ were added in the culture. The proliferation was determined by BrdU cell proliferation assays (F). IFN- $\gamma$ production in the supernatants was examined by ELISA (G). Representative plots from three independent experiments were shown. The data were pooled from five independent experiments with similar results. ${ }^{* *} p<0.01 ;{ }^{* * *} p<0.001$; n.s., no significance.

antibodies led to significant increase of risks for autoimmune diseases (e.g., type 1 diabetes), which was due to that PD-1 mAb treatment abrogated endogenous signaling axis of PD-L1/PD-1, thereby pathogenically activated autoreactive $\mathrm{T}$ cells and ultimately caused the onset of autoimmune diseases (33-35); (b)
PD-1 expression is limited to activated $\mathrm{T}$ and $\mathrm{B}$ cells as well as myeloid cells, implying that PD-L1/PD-1 signals is an important brake to avoid excessive immune response. Since this signaling axis has minimal effects on the priming of immune reaction, augmenting $\mathrm{PD}-\mathrm{L} 1 / \mathrm{PD}-1$ signals may have potentials to 

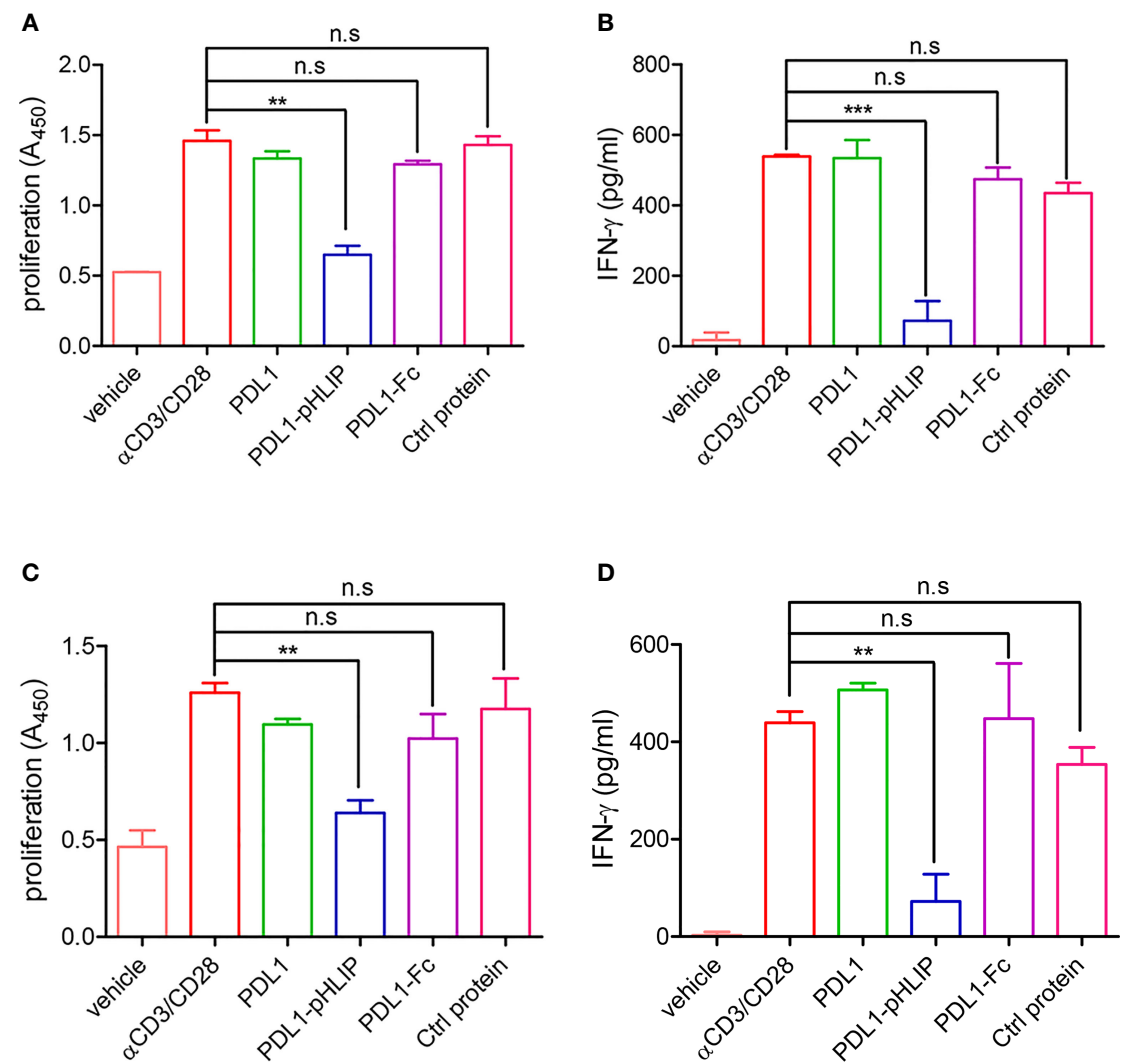

FIGURE 6 | The capacity of soluble PD-L1-pHLIP to inhibit lymphocyte proliferation and IFN- $\gamma$ production under acidic conditions. (A, B) Mouse lymphocytes were stimulated with $\alpha C D 3 / C D 28$ antibodies in the presence of soluble PD-L1/PD-L1-pHLIP/PD-L1-Fc $(0.1 \mu \mathrm{g} / \mathrm{ml})$ for $72 \mathrm{~h}$ in $\mathrm{pH} 6.3$ buffer. The proliferation was determined by BrdU cell proliferation assays (A). IFN- $\gamma$ production in the supernatants was examined by ELISA (B). (C, D) Mouse lymphocytes were stimulated with $\alpha C D 3 / C D 28$ antibodies in the presence of soluble PD-L1/PD-L1-pHLIP/PD-L1-Fc $(0.1 \mu \mathrm{g} / \mathrm{ml})$ for $72 \mathrm{~h}$ in buffer containing $10 \mathrm{mM}$ lactic acid. The proliferation was determined by BrdU cell proliferation assays (C). IFN- $\gamma$ production in the supernatants was examined by ELISA (D). The data were pooled from five independent experiments with similar results. ${ }^{\star \star} p<0.01 ;{ }^{* \star} p<0.001$; n.s., no significance.

normalize immune responses (36); (c) PD-L1 is widely expressed in nonlymphoid tissues as well as on dendritic cells, allowing for regulation of potentially autoreactive lymphocytes at sites of immune activation as well as at effector sites. This may be a particularly important mechanism in limiting activities of both $\mathrm{T}$ and $\mathrm{B}$ cells in multiple organs where PD-L1 is highly expressed $(37,38)$; (d) Since that excessive inflammatory responses is partly ascribed to dampened PD-L1/PD-1 signals (39), we speculate that the increase of PD-L1 abundance and restoration of signaling strength in the site of inflammation can alleviate inflammatory reaction and tissue damage; (e) $\mathrm{PD}-\mathrm{L} 1$ is type 1 membrane protein interacting with PD-1 at the state of monomers, which enables perfect recognition of the dissociated extracellular region of PD-L1 to membrane-bound PD-1 $(40,41)$; (f) The dissociated ectodomain of PD-L1 functions to antagonize PD-L1/PD-1 engagement. Upon anchoring the membrane by pHLIPmediated insertion, pHLIP-modified PD-L1 plays an immunesuppressive role as full-length PD-L1.

Of note, there are some studies suggesting that soluble PD-L1 can inhibit T-cell activity in vitro (42-44). Others suggest that this form of PD-L1 cannot do this but acts as antagonist to block the engagement of naïve PD-L1 with PD-1 on the surface of T cells (45-47). It is worthy to note that plate-coated PD-L1 protein can actively inhibit T-cell response (48-50). In addition, PD-L1-Fc administration exhibited therapeutic efficacy in several animal models of inflammatory diseases $(48,51,52)$. This discrepancy can be resolved by the fact that crosslinking or aggregated IgG is required for activation of NK or T cells via Fc $\gamma$ RIIA or Fc $\gamma$ RIII (53, 54). Consequently, it is conceivable to assume that crosslinking of PD-L1 to PD-1 is necessary for inhibition of T-cell activity in vitro. Although soluble PD-L1 can bind to PD-1 in vitro, this form has no crosslinking activity so that it cannot elicit PD-1-mediated immune-suppressive response. The therapeutic effects of PD-L1$\mathrm{Fc}$ in vivo may be attributed to $\mathrm{Fc}$-mediated crosslinking of PD-L1 and PD-1 via interaction with Fc receptors on immune cells.

A recent study demonstrated that in NOD mice hematopoietic stem progenitor cells (HSPCs) were deficient in PD-L1 and transfusion of genetically engineered or pharmacologically modulated HSPCs overexpressing PD-L1 inhibited autoimmune response and reverted diabetes (9). However, given persistent overexpression of PD-L1 in vivo, this regimen could result in widespread immune suppression 
leading to increased risks for infection and cancer. Relatively, if our strategy is validated to be efficacious in vivo, the nonspecific immune suppression can be avoided and genetic manipulation can be prevented. The therapeutic efficacy might be largely affected by $\mathrm{pH}$. When $\mathrm{pH}$ value dropped from 6.5 to 6.3 or even lower, the membrane-inserting ability of PD-L1-pHLIP improved significantly with increased membrane-bound abundances. This can be interpreted by the fact that at $\mathrm{pH} 6.4$ pHLIPs exist as a mixture of a largely unstructured population (state II) and an inserted $\alpha$-helical population (state III) (28). In lower $\mathrm{pH}(<6.4)$ buffer, pHLIPs exist at more stable membraneinserted states thereby are anchored tightly on the surface of cells. In addition, the different $\mathrm{pH}$ in various diseases and dynamic alteration of $\mathrm{pH}$ at different stages of one disease may have an effect on membrane insertion and accumulation of pHLIPs in the lesion, which might greatly influence the therapeutic efficacy of PD-L1-pHLIP. This issue can be resolved in part by crosslinking pHLIP variants since some variants have ability of enhanced targeting and greater retention in acidic tissues in comparison with wild-type pHLIPs. In conclusions, our study have demonstrated that the extracellular region of PD-L1 tethering pHLIPs exhibits potently immune-suppressive activity and provide a potentially novel regimen for the treatment of autoimmune diseases and other T-cell-mediated inflammatory diseases.

\section{DATA AVAILABILITY STATEMENT}

The original contributions presented in the study are included in the article/Supplementary Material. Further inquiries can be directed to the corresponding authors.

\section{REFERENCES}

1. Ansari MJ, Salama AD, Chitnis T, Smith RN, Yagita H, Akiba H, et al. The Programmed Death-1 (PD-1) Pathway Regulates Autoimmune Diabetes in Nonobese Diabetic (NOD) Mice. J Exp Med (2003) 198:63-9. doi: 10.1084/ jem.20022125

2. Khoury SJ, Sayegh MH. The Roles of the New Negative T Cell Costimulatory Pathways in Regulating Autoimmunity. Immunity (2004) 20:529-38. doi: 10.1016/S1074-7613(04)00116-5

3. Keir ME, Liang SC, Guleria I, Latchman YE, Qipo A, Albacker LA, et al. Tissue Expression of PD-L1 Mediates Peripheral T Cell Tolerance. J Exp Med (2006) 203:883-95. doi: 10.1084/jem.20051776

4. Nishimura H, Nose M, Hiai H, Minato N, Honjo T. Development of LupusLike Autoimmune Diseases by Disruption of the PD-1 Gene Encoding an ITIM Motif-Carrying Immunoreceptor. Immunity (1999) 11:141-51. doi: 10.1016/S1074-7613(00)80089-8

5. Nishimura H, Okazaki T, Tanaka Y, Nakatani K, Hara M, Matsumori A, et al. Autoimmune Dilated Cardiomyopathy in PD-1 Receptor-Deficient Mice. Science (2001) 291:319-22. doi: 10.1126/science.291.5502.319

6. Okazaki T, Tanaka Y, Nishio R, Mitsuiye T, Mizoguchi A, Wang J, et al. Autoantibodies Against Cardiac Troponin I are Responsible for Dilated Cardiomyopathy in PD-1-Deficient Mice. Nat Med (2003) 9:1477-83. doi: $10.1038 / \mathrm{nm} 955$

7. Latchman YE, Liang SC, Wu Y, Chernova T, Sobel RA, Klemm M, et al. PDL1-Deficient Mice Show That PD-L1 on T Cells, Antigen-Presenting Cells, and Host Tissues Negatively Regulates T Cells. Proc Natl Acad Sci USA (2004) 101:10691-6. doi: 10.1073/pnas.0307252101

\section{ETHICS STATEMENT}

The studies involving human participants were reviewed and approved by The Ethics Committee of the Chinese PLA General Hospital. The patients/participants provided their written informed consent to participate in this study. The animal study was reviewed and approved by The Ethics Committee of the Academy of Beijing Institute of Pharmacology and Toxicology.

\section{AUTHOR CONTRIBUTIONS}

YiS and LH performed the experiments and prepared the manuscript. PY, MZ, and XW were involved in optimization of the experimental protocols. HX, CQ, JW, LL, JF, and YZ provided methodological support. YW, YaS, and GC conceived and guided the study. All authors contributed to the article and approved the submitted version.

\section{FUNDING}

This work is supported by the National Natural Science Foundation of China $(81672803,81871252)$.

\section{SUPPLEMENTARY MATERIAL}

The Supplementary Material for this article can be found online at: https://www.frontiersin.org/articles/10.3389/fimmu.2021.794226/ full\#supplementary-material

8. Wang J, Yoshida T, Nakaki F, Hiai H, Okazaki T, Honjo T. Establishment of NOD-Pdcd1-/- Mice as an Efficient Animal Model of Type I Diabetes. Proc Natl Acad Sci USA (2005) 102:11823-8. doi: 10.1073/pnas.0505 497102

9. Ben Nasr M, Tezza S, D'Addio F, Mameli C, Usuelli V, Maestroni A, et al. PDL1 Genetic Overexpression or Pharmacological Restoration in Hematopoietic Stem and Progenitor Cells Reverses Autoimmune Diabetes. Sci Transl Med (2017) 9:eaam7543. doi: 10.1126/scitranslmed.aam7543

10. Wang CJ, Chou FC, Chu CH, Wu JC, Lin SH, Chang DM, et al. Protective Role of Programmed Death 1 Ligand 1 (PD-L1)in Nonobese Diabetic Mice: The Paradox in Transgenic Models. Diabetes (2008) 57:1861-9. doi: 10.2337/ db07-1260

11. Holmdahl R, Malmström V, Burkhardt H. Autoimmune Priming, Tissue Attack and Chronic Inflammation - the Three Stages of Rheumatoid Arthritis. Eur J Immunol (2014) 44:1593-9. doi: 10.1002/eji.201444486

12. Muñoz LE, Janko C, Schulze C, Schorn C, Sarter K, Schett G, et al. Autoimmunity and Chronic Inflammation - Two Clearance-Related Steps in the Etiopathogenesis of SLE. Autoimmun Rev (2010) 10:38-42. doi: 10.1016/j.autrev.2010.08.015

13. Rodríguez-Prados JC, Través PG, Cuenca J, Rico D, Aragonés J, Martín-Sanz P, et al. Substrate Fate in Activated Macrophages: A Comparison Between Innate, Classic, and Alternative Activation. J Immunol (2010) 185:605-14. doi: 10.4049/jimmunol.0901698

14. Krawczyk CM, Holowka T, Sun J, Blagih J, Amiel E, DeBerardinis RJ, et al. Toll-Like Receptor-Induced Changes in Glycolytic Metabolism Regulate Dendritic Cell Activation. Blood (2010) 115:4742-9. doi: 10.1182/blood2009-10-249540 
15. Michalek RD, Gerriets VA, Jacobs SR, Macintyre AN, MacIver NJ, Mason EF, et al. Cutting Edge: Distinct Glycolytic and Lipid Oxidative Metabolic Programs Are Essential for Effector and Regulatory CD4+ T Cell Subsets. J Immunol (2011) 186:3299-303. doi: 10.4049/jimmunol.1003613

16. Doughty CA, Bleiman BF, Wagner DJ, Dufort FJ, Mataraza JM, Roberts MF, et al. Antigen Receptor-Mediated Changes in Glucose Metabolism in B Lymphocytes: Role of Phosphatidylinositol 3-Kinase Signaling in the Glycolytic Control of Growth. Blood (2006) 107:4458-65. doi: 10.1182/ blood-2005-12-4788

17. He L, Gomes AP, Wang X, Yoon SO, Lee G, Nagiec MJ, et al. Mtorc1Dependent Metabolic Reprogramming is a Prerequisite for NK Cell Effector Function. J Immunol (2014) 193:4477-84. doi: 10.4049/jimmunol.1401558

18. Everts B, Amiel E, Huang SC, Smith AM, Chang CH, Lam WY, et al. TLRDriven Early Glycolytic Reprogramming via the Kinases TBK1-IKKE Supports the Anabolic Demands of Dendritic Cell Activation. Nat Immunol (2014) 15:323-32. doi: 10.1038/ni.2833

19. Shi LZ, Wang R, Huang G, Vogel P, Neale G, Green DR, et al. HIF1alphaDependent Glycolytic Pathway Orchestrates a Metabolic Checkpoint for the Differentiation of TH17 and Treg Cells. J Exp Med (2011) 208:1367-76. doi: $10.1084 /$ jem. 20110278

20. Haas R, Smith J, Rocher-Ros V, Nadkarni S, Montero-Melendez T, D'Acquisto F, et al. Lactate Regulates Metabolic and Pro-Inflammatory Circuits in Control of T Cell Migration and Effector Functions. PloS Biol (2015) 13:e1002202. doi: 10.1371/journal.pbio.1002202

21. Nugent SG, Kumar D, Rampton DS, Evans DF. Intestinal Luminal $\mathrm{pH}$ in Inflammatory Bowel Disease: Possible Determinants and Implications for Therapy With Aminosalicylates and Other Drugs. Gut (2001) 48:571-7. doi: 10.1136/gut.48.4.571

22. Suetrong B, Walley KR. Lactic Acidosis in Sepsis: It's Not All Anaerobic: Implications for Diagnosis and Management. Chest (2016) 149:252-61. doi: 10.1378/chest.15-1703

23. Hunt JF, Rath P, Rothschild KJ, Engelman DM. Spontaneous, pH-Dependent Membrane Insertion of a Transbilayer Alpha-Helix. Biochemistry (1997) 36:15177-92. doi: 10.1021/bi970147b

24. Deacon JC, Engelman DM, Barrera FN. Targeting Acidity in Diseased Tissues: Mechanism and Applications of the Membrane-Inserting Peptide, pHLIP. Arch Biochem Biophys (2015) 565:40-8. doi: 10.1016/j.abb.2014.11.002

25. Reshetnyak YK, Andreev OA, Lehnert U, Engelman DM. Translocation of Molecules Into Cells by $\mathrm{pH}$-Dependent Insertion of a Transmembrane Helix. Proc Natl Acad Sci USA (2006) 103:6460-5. doi: 10.1073/pnas.0601463103

26. Wyatt LC, Lewis JS, Andreev OA, Reshetnyak YK, Engelman DM. Applications of pHLIP Technology for Cancer Imaging and Therapy. Trends Biotechnol (2017) 35:653-64. doi: 10.1016/j.tibtech.2017.03.014

27. Wehr J, Sikorski EL, Bloch E, Feigman MS, Ferraro NJ, Baybutt TR, et al. pHDependent Grafting of Cancer Cells With Antigenic Epitopes Promotes Selective Antibody-Mediated Cytotoxicity. J Med Chem (2020) 63:3713-22. doi: 10.1021/acs.jmedchem.0c00016

28. Shu NS, Chung MS, Yao L, An M, Qiang W. Residue-Specific Structures and Membrane Locations of pH-Low Insertion Peptide by Solid-State Nuclear Magnetic Resonance. Nat Commun (2015) 6:7787. doi: 10.1038/ncomms8787

29. Mahoney KM, Rennert PD, Freeman GJ. Combination Cancer Immunotherapy and New Immunomodulatory Targets. Nat Rev Drug Discovery (2015) 14:561-84. doi: 10.1038/nrd4591

30. Serio I, Tovoli F. Rheumatoid Arthritis: New Monoclonal Antibodies. Drugs Today (Barc) (2018) 54:219-30. doi: 10.1358/dot.2018.54.3.2788019

31. Thompson C, Davies R, Choy E. Anti Cytokine Therapy in Chronic Inflammatory Arthritis. Cytokine (2016) 86:92-9. doi: 10.1016/j.cyto.2016.07.015

32. Schwartz DM, Bonelli M, Gadina M, O'Shea JJ. Type I/II Cytokines, JAKs, and New Strategies for Treating Autoimmune Diseases. Nat Rev Rheumatol (2016) 12:25-36. doi: 10.1038/nrrheum.2015.167

33. Young A, Quandt Z, Bluestone JA. The Balancing Act Between Cancer Immunity and Autoimmunity in Response to Immunotherapy. Cancer Immunol Res (2018) 6:1445-52. doi: 10.1158/2326-6066.CIR-18-0487

34. Dougan M. Checkpoint Blockade Toxicity and Immune Homeostasis in the Gastrointestinal Tract. Front Immunol (2017) 8:1547. doi: 10.3389/ fimmu.2017.01547

35. Wang DY, Salem JE, Cohen JV, Chandra S, Menzer C, Ye F, et al. Fatal Toxic Effects Associated With Immune Checkpoint Inhibitors: A Systematic Review and Meta-Analysis. JAMA Oncol (2018) 4:1721-8. doi: 10.1001/ jamaoncol.2018.3923

36. Sanmamed MF, Chen L. A Paradigm Shift in Cancer Immunotherapy: From Enhancement to Normalization. Cell (2018) 175:313-26. doi: 10.1016/ j.cell.2018.09.035

37. Dong H, Zhu G, Tamada K, Chen L. B7-H1, a Third Member of the B7 Family, Co-Stimulates T-Cell Proliferation and Interleukin-10 Secretion. Nat Med (1999) 5:1365-9. doi: 10.1038/70932

38. Freeman GJ, Long AJ, Iwai $\mathrm{Y}$, Bourque $\mathrm{K}$, Chernova $\mathrm{T}$, Nishimura $\mathrm{H}$, et al. Engagement of the PD-1 Immunoinhibitory Receptor by a Novel B7 Family Member Leads to Negative Regulation of Lymphocyte Activation. J Exp Med (2000) 192:1027-34. doi: 10.1084/jem.192.7.1027

39. Jiang X, Wang J, Deng X, Xiong F, Ge J, Xiang B, et al. Role of the Tumor Microenvironment in PD-L1/PD-1-Mediated Tumor Immune Escape. Mol Cancer (2019) 18:10. doi: 10.1186/s12943-018-0928-4

40. Greenwald RJ, Freeman GJ, Sharpe AH. The B7 Family Revisited. Annu Rev Immunol (2005) 23:515-48. doi: 10.1146/annurev.immunol.23.021704.115611

41. Zhang X, Schwartz JC, Guo X, Bhatia S, Cao E, Lorenz M, et al. Structural and Functional Analysis of the Costimulatory Receptor Programmed Death-1. Immunity (2004) 20:337-47. doi: 10.1016/S1074-7613(04)00051-2

42. Wang G, Hu P, Yang J, Shen G, Wu X. The Effects of PDL-Ig on Collagen-Induced Arthritis. Rheumatol Int (2011) 31:513-9. doi: 10.1007/s00296-009-1249-0

43. Frigola X, Inman BA, Lohse CM, Krco CJ, Cheville JC, Thompson RH, et al. Identification of a Soluble Form of B7-H1 That Retains Immunosuppressive Activity and is Associated With Aggressive Renal Cell Carcinoma. Clin Cancer Res (2011) 17:1915-23. doi: 10.1158/1078-0432.CCR-10-0250

44. Hassounah NB, Malladi VS, Huang Y, Freeman SS, Beauchamp EM, Koyama $S$, et al. Identification and Characterization of an Alternative Cancer-Derived PD-L1 Splice Variant. Cancer Immunol Immunother (2019) 68:407-20. doi: 10.1007/s00262-018-2284-Z

45. Gong B, Kiyotani K, Sakata S, Nagano S, Kumehara S, Baba S, et al. Secreted PD-L1 Variants Mediate Resistance to PD-L1 Blockade Therapy in non-Small Cell Lung Cancer. J Exp Med (2019) 216:982-1000. doi: 10.1084/jem.20180870

46. Hirahara K, Ghoreschi K, Yang XP, Takahashi H, Laurence A, Vahedi G, et al. Interleukin-27 Priming of T Cells Controls IL-17 Production in Trans via Induction of the Ligand PD-L1. Immunity (2012) 36:1017-30. doi: 10.1016/ j.immuni.2012.03.024

47. Ng KW, Attig J, Young GR, Ottina E, Papamichos SI, Kotsianidis I, et al. Soluble PD-L1 Generated by Endogenous Retroelement Exaptation is a Receptor Antagonist. Elife (2019) 8:e50256. doi: 10.7554/eLife.50256

48. Ozkaynak E, Wang L, Goodearl A, McDonald K, Qin S, O'Keefe T, et al. Programmed Death-1 Targeting can Promote Allograft Survival. J Immunol (2002) 169:6546-53. doi: 10.4049/jimmunol.169.11.6546

49. Kroemer G, Zitvogel L. Immune Checkpoint Inhibitors. J Exp Med (2021) 218 (3):e20201979. doi: 10.1084/jem.20201979

50. Zhou J, Mahoney KM, Giobbie-Hurder A, Zhao F, Lee S, Liao X, et al. Soluble PDL1 as a Biomarker in Malignant Melanoma Treated With Checkpoint Blockade. Cancer Immunol Res (2017) 5:480-92. doi: 10.1158/2326-6066.CIR-16-0329

51. Tian M, Zhang Y, Liu Z, Sun G, Mor G, Liao A. The PD-1/PD-L1 Inhibitory Pathway is Altered in Pre-Eclampsia and Regulates T Cell Responses in PreEclamptic Rats. Sci Rep (2016) 6:27683. doi: 10.1038/srep27683

52. Song MY, Hong CP, Park SJ, Kim JH, Yang BG, Park Y, et al. Protective Effects of Fc-Fused PD-L1 on Two Different Animal Models of Colitis. Gut (2015) 64:260-71. doi: 10.1136/gutjnl-2014-307311

53. Arase N, Arase H, Hirano S, Yokosuka T, Sakurai D, Saito T. IgE-Mediated Activation of NK Cells Through Fc Gamma RIII. J Immunol (2003) 170:30548. doi: 10.4049/jimmunol.170.6.3054

54. Holgado MP, Sananez I, Raiden S, Geffner JR, Arruvito L. CD32 Ligation Promotes the Activation of CD4(+) T Cells. Front Immunol (2018) 9:2814. doi: $10.3389 /$ fimmu.2018.02814

Conflict of Interest: The authors declare that the research was conducted in the absence of any commercial or financial relationships that could be construed as a potential conflict of interest.

Publisher's Note: All claims expressed in this article are solely those of the authors and do not necessarily represent those of their affiliated organizations, or those of the publisher, the editors and the reviewers. Any product that may be evaluated in 
this article, or claim that may be made by its manufacturer, is not guaranteed or endorsed by the publisher.

Copyright $\odot 2021$ Sun, Hu, Yang, Zhang, Wang, Xiao, Qiao, Wang, Luo, Feng, Zheng, Wang, Shi and Chen. This is an open-access article distributed under the terms of the Creative Commons Attribution License (CC BY). The use, distribution or reproduction in other forums is permitted, provided the original author(s) and the copyright owner(s) are credited and that the original publication in this journal is cited, in accordance with accepted academic practice. No use, distribution or reproduction is permitted which does not comply with these terms. 